\title{
A Protein from Cajanus indicus Spreng Protects Liver and Kidney against Mercuric Chloride-Induced Oxidative Stress
}

\author{
Ayantika GHosh and Parames Chandra SIL* \\ Department of Chemistry, Bose Institute; 93/1, Acharya Prafulla Chandra Road, Kolkata-700009, India. \\ Received March 5, 2008; accepted June 2, 2008; published online June 10, 2008
}

\begin{abstract}
Mercuric chloride $\left(\mathrm{HgCl}_{2}\right)$ is a widespread environmental toxin that affects mainly liver and kidney. The present study has been carried out to investigate the protective action of a protein (the CI protein) isolated from the herb, Cajanus indicus Spreng against $\mathrm{HgCl}_{2}$ induced renal and hepatic toxicities in mice. Intraperitoneal administration of $\mathrm{HgCl}_{2}$ at a dose of $5 \mathrm{mg} / \mathrm{kg}$ body weight for $1 \mathrm{~d}$ significantly reduced the activities of antioxidant enzymes like superoxide dismutase (SOD), catalase (CAT) and glutathione peroxidase (GPx). Moreover, it also depleted the glutathione to oxidized glutathione (GSH/GSSG) ratio. In addition, $\mathrm{HgCl}_{2}$ increased the activities of serum marker enzymes (namely, glutamate pyruvate transaminase, GPT and alkaline phosphatase, ALP), creatinine, blood urea nitrogen and serum tumor necrosis factor alpha (TNF- $\alpha$ ) level along with hepatic and renal lipid peroxidation. Besides, application of $\mathrm{HgCl}_{2}$ to hepatocytes increased reactive oxygen species production and reduced the total antioxidant activity of the treated hepatocytes. Treatment with the CI protein intraperitonealy at a dose of $2 \mathrm{mg} / \mathrm{kg}$ body weight before or after $\mathrm{HgCl}_{2}$ administration showed that it could scavenge free radicals in vitro and protect the alterations of the antioxidant molecules and the other parameters used in this particular study. Histological studies also revealed a milder lesion in kidney and liver samples of the CI protein treated mice compared to mice treated with $\mathrm{HgCl}_{2}$ alone. Effects of a known antioxidant $N$-acetylcysteine have been used to compare its action to that of the CI protein.
\end{abstract}

Key words mercuric chloride; oxidative stress; hepato-renal disorder; Cajanus indicus; CI protein; tissue protection

There is growing evidence that heavy metals, in general, and mercurial compounds, in particular, are toxic to humans. Large populations are currently exposed to low levels of mercury owing to the use of mercury $(\mathrm{Hg})$ pesticides in agriculture or as components of batteries in fluorescent light bulbs. $\mathrm{Hg}$ exists in a wide variety of physical and chemical states, each of which has unique characteristics for target organ specificity. Exposure to $\mathrm{Hg}$ vapor and to organic $\mathrm{Hg}$ compounds specifically affects the central nervous system, while the kidney, liver and gastrointestinal tract is the target organ for inorganic $\mathrm{Hg}$ compounds.

Reactive oxygen species (ROS) have been involved as mediators in ischemic, toxin and immune mediated tissue damages. $^{1-3)}$ Stacey and Kappas ${ }^{4)}$ reported the role of oxidative stress in mercury toxicity. Their view was also supported by the findings of Woods et al. ${ }^{5)}$ that mercuric chloride $\left(\mathrm{HgCl}_{2}\right)$ imposes a loss of antioxidant potential in terms of glutathione (GSH) and glutathione peroxidase (GPx) and promotes free radical formation via thiol complexation. The increase in ROS generation is also accompanied by a decrease in the antioxidant enzymes catalase and glutathione peroxidase. Besides, lipid peroxidation has also been proposed to be occurring in hepatic and renal tissues following parenteral administration of $\mathrm{HgCl}_{2}{ }^{6}{ }^{6,7)} \mathrm{Hg}(\mathrm{II})$ can also inactivate a number of enzymes by blocking the functional sites through binding to sulfhydryl groups, which are part of catalytic or binding domains. ${ }^{8}$ ) Covalent binding to sulfhydryl groups by $\mathrm{Hg}$ (II) alters protein conformation, creates protein adducts through modification of side chains and finally leads to changes in protein shape and activity. ${ }^{9)}$

Nevertheless, the evidence for pathogenic role of $\mathrm{HgCl}_{2}$ induced oxidative stress is confusing as some studies do not point to increased peroxide formation in kidneys. ${ }^{10,11)}$ Moreover, administration of several antioxidants, too, failed to provide protection in $\mathrm{HgCl}_{2}$-induced increase in renal lipid peroxidation. $^{12)}$

A $43 \mathrm{kDa}$ protein (the CI protein) molecule ${ }^{13}$ was isolated and purified in our laboratory from the leaves of Cajanus indicus Spreng, a popular herbal plant in several tropical countries. In India the traditional uses of Cajanus indicus Spreng are believed to be in treatment for liver disorders, jaundice, hepatomegaly diabetes, hypoglycemia and cardiovascular disease. ${ }^{14,15)}$ It has been found to be effective in reducing hepatotoxicity induced by toxins such as fluoride, cadmium chloride, chloroform, thioacetamide, etc., both in vivo and in vitro. ${ }^{16-22)}$

$N$-Acetylcysteine (NAC) can act as a source of thiols, stimulate GSH synthesis, enhance GPx activity, promote detoxification, and act directly on reactive oxidant radicals. Evidence indicates that NAC is useful as a chelating agent in the therapy of acute heavy metal poisoning.

In the present study we, therefore, set our aim to compare the protective effects of the CI protein with that of NAC against $\mathrm{HgCl}_{2}$ induced acute hepatic and renal tissue toxicity. For this purpose, $\mathrm{HgCl}_{2}$-induced hepatotoxicity was evaluated by determining the level of serum marker enzymes, glutamate pyruvate transaminase (GPT) and alkaline phosphatase (ALP). Renal dysfunctions in terms of creatinine and blood urea nitrogen (BUN) were also measured from the serum in all the experimental mice groups. In addition, tumor necrosis factor-alpha (TNF- $\alpha$ ) was measured from the serum of treated mice groups. Intracellular ROS production and total antioxidant power was also measured from $\mathrm{HgCl}_{2}$ and $\mathrm{HgCl}_{2}+\mathrm{CI}$ protein treated hepatocytes. The activities of endogenous antioxidant enzymes, such as superoxide dismutase (SOD), catalase (CAT), and glutathione peroxidase (GPx) were measured from liver and kidney tissue homogenates. Further, the extent of lipid peroxidation and glutathione to oxidized glutathione (GSH/GSSG) ratio were also estimated from hepatic and renal samples. To assess the ultra 
structural changes of the liver and kidney, histological studies were conducted from the liver and kidney sections of normal mice, mice treated with $\mathrm{HgCl}_{2}$ alone, and mice treated with the $\mathrm{CI}$ protein both prior and post to $\mathrm{HgCl}_{2}$ administration. Effect of a non relevant protein, bovine serum albumin (BSA), on the $\mathrm{HgCl}_{2}$-induced hepatic and renal toxicity was also included in the study.

\section{MATERIALS AND METHODS}

Chemicals Kits for the measurement of serum GPT, ALP, BUN and creatinine were purchased from Span diagnostics Ltd., India. Sodium pyrophosphates, Bradford reagent, bovine sera albumin (BSA), 2'7'-dichlorodihydro fluorescien di-acetate $\left(\mathrm{H}_{2} \mathrm{DCFDA}\right)$ were made available from Sigma Chemical Company (St. Louis, MO, U.S.A.). $\mathrm{HgCl}_{2}$ and all other chemicals used in the study were obtained from Sisco research laboratory, India.

Animals Swiss albino male mice of body weight $25 \pm 2 \mathrm{~g}$ were used in the experiments. The animals were kept for two weeks prior to the experiment to acclimatize with the lab conditions. All of them had free access to standard diet and water ad libitum. The study was conducted in conformity with standard experimental animals study ethical protocols.

Preparation of Homogeneous Protein from the Leaves of Cajanus indicus Spreng The CI protein was purified from the leaves of young Cajanus indicus Spreng plants. ${ }^{13)}$ Briefly, fresh young leaves were homogenized in $20 \mathrm{~mm}$ Tris- $\mathrm{HCl}$ buffer, $\mathrm{pH} 7.4$ and were saturated with $60 \%$ ammonium sulphate. The pellet was reconstituted and dialysed in Tris- $\mathrm{HCl}$ buffer, $\mathrm{pH}$ 7.4; passed through DEAE Sephadex column and eluted using a linear gradient of $0-1 \mathrm{M} \mathrm{NaCl}$ in Tris- $\mathrm{HCl}$ buffer, $\mathrm{pH}$ 7.4. The fraction showing hepatoprotective activity was desalted, concentrated and applied on a Sephadex G-50 column. The protein fraction showing maximum biological activity was finally subjected to a reverse phase chromatography on a $\mathrm{C}-18$ hydrophobic column attached to HPLC. Homogeneity of preparation and the molecular weight of the protein were determined using SDS polyacrylamide gel electrophoresis.

Protein Estimation Protein concentration was measured according to the method of Bradford ${ }^{23)}$ using crystalline bovine serum albumin (BSA) as standard.

Experimental Design Swiss albino male mice were divided into eight groups, each consisting of 6 animals.

Mice were intraperitoneally injected with:

i) $0.9 \% \mathrm{NaCl}$ for the Control (C) group,

ii) a single dose of $5 \mathrm{mg} / \mathrm{kg}$ mercuric chloride $\left(\mathrm{HgCl}_{2}\right)$ for a day and decapitated after 1,2 and $3 \mathrm{~d}-\mathrm{Hg}$ group; (this dosage has been determined from previous stud-

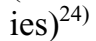

iii) the CI protein at a dose of $2 \mathrm{mg} / \mathrm{kg}$ body weight for $3 \mathrm{~d}$ before $\mathrm{HgCl}_{2}$ application for a day and decapitated after 1,2 , and $3 \mathrm{~d}$ for the protein- $\mathrm{Hg}$ group

iv) the CI protein at a dose of $2 \mathrm{mg} / \mathrm{kg}$, for 1,2 and $3 \mathrm{~d}$ respectively after $\mathrm{HgCl}_{2}$ administration for a day and sacrificed after $24 \mathrm{~h}$ from the last treatment.

v) $\mathrm{N}$-acetylcysteine at a dose of $150 \mathrm{mg} / \mathrm{kg}$ for $3 \mathrm{~d}$ before $\mathrm{HgCl}_{2}$ injection for a day and sacrificed after 1, 2, and $3 \mathrm{~d}$ for $\mathrm{NAC}-\mathrm{Hg}$ group

vi) $\quad N$-acetylcysteine at a dose of $150 \mathrm{mg} / \mathrm{kg}$, for $3 \mathrm{~d}$ after
$\mathrm{HgCl}_{2}$ injection for a day and sacrificed after 1,2 , and $3 \mathrm{~d}$ for $\mathrm{Hg}-\mathrm{NAC}$ group

vii) mice were treated with $2 \mathrm{mg} / \mathrm{kg}$ body weight of BSA before $\mathrm{HgCl}_{2}$ injection for a day and sacrificed after 1, 2 , and $3 \mathrm{~d}$, in the same way as that of the protein for $\mathrm{BSA}-\mathrm{Hg}$ group

viii) mice were treated with $2 \mathrm{mg} / \mathrm{kg}$ body weight of BSA after $\mathrm{HgCl}_{2}$ injection for a day and sacrificed after 1 , 2 , and $3 \mathrm{~d}$, in the same way as that of the protein for $\mathrm{Hg}-\mathrm{BSA}$ group

Assessment of Liver and Kidney Functions Blood samples collected from puncturing mice heart were kept overnight to clot and then centrifuged at $3000 \mathrm{~g}$ for $10 \mathrm{~min}$. Serum GPT was measured by 2,4-DNPH method of Reitman and Frankel, ${ }^{25}$ ) ALP was estimated by Kind and King's method. ${ }^{26)}$ Blood urea nitrogen (BUN) was determined spectrophotometrically from serum samples using the method of diacetylmonooxime, DAM. ${ }^{27,28)}$ Creatinine was measured according to the method of Bonsnes and Taussky. ${ }^{29)}$

Measurement of Serum TNF- $\alpha$ TNF- $\alpha$ levels were determined from sera of mice treated $5 \mathrm{mg} / \mathrm{kg}$ body weight of $\mathrm{HgCl}_{2}$ alone or after the protein treatment $(2 \mathrm{mg} / \mathrm{kg}$ body weight) using sandwich ELISA. ${ }^{30}$ Rat anti-mouse TNF- $\alpha$ monoclonal antibody (mAb) (IMGENEX, India) was diluted to $2 \mathrm{mg} / \mathrm{ml}$ in $0.1 \mathrm{M} \mathrm{NaHCO}_{3}$, pH 8.2. Wells of a 96 flat-bottomed probind assay plate (Becton Dickinson) were coated with $50 \mathrm{mg} /$ well of the capture antibody and incubated overnight at $4{ }^{\circ} \mathrm{C}$. The plates were washed 2 times in $350 \mathrm{ml}$ of PBS Tween-20. Three hundred fifty milliliters of blocking agent $(1 \times$ PBS-Tween 20 with 5\% BSA) was added per well and incubated for $2 \mathrm{~h}$ at room temperature and washed 2 times. Standard recombinant mouse TNF- $\alpha$ (Genzyme) diluted serially in the blocking agent to generate a standard curve and samples were added at the rate of $100 \mathrm{ml} /$ well in triplicate and incubated at $4{ }^{\circ} \mathrm{C}$ overnight and washed 4 times. The serum (sample) concentration used in the assay was $10 \mathrm{ng} /$ well. Biotinylated anti-mouse TNF- $\alpha$ clone mp6XT3 diluted to $1 \mathrm{ml} / \mathrm{ml}$ in the blocking agent was added and washed 6 times. Then $4 \times 10^{3} / \mathrm{ml}$ of the peroxidase-conjugated streptavidin diluted $1: 3 \mathrm{v} / \mathrm{v}$ in the blocking agent was added at $100 \mathrm{ml} /$ well, incubated for $30 \mathrm{~min}$ at room temperature and washed 8 times. Finally $20 \mathrm{mg}$ of a substrate, phenylene diamine, in $25 \mathrm{ml}$ of $0.1 \mathrm{M}$ citric acid, $25 \mathrm{ml}$ of $0.2 \mathrm{M}$ $\mathrm{NaHPO}_{4} / 2 \mathrm{H}_{2} \mathrm{O}$ and $1 \mathrm{ml}$ of $30 \% \mathrm{H}_{2} \mathrm{O}_{2}$ was added at the rate of $100 \mathrm{ml} /$ well and the color was allowed to develop at room temperature for $90 \mathrm{~min}$. The color reaction was stopped using $3 \mathrm{~N}_{2} \mathrm{SO}_{4}$ and read at OD $450 \mathrm{~nm}$ using a microplate reader. TNF- $\alpha$ values were calculated from the standard curve as mean \pm S.D. The sensitivity of the assay was $50 \mathrm{pg} / \mathrm{ml}$.

Hepatocyte Isolation Hepatocytes were isolated from mice liver ${ }^{19}$ ) by the perfusion technique with collagenase type I at $37^{\circ} \mathrm{C}$. The cells were suspended in DMEM containing FBS and the suspension was adjusted to obtain $c a$. $2 \times 10^{6}$ cells $/ \mathrm{ml}$. About $1 \mathrm{ml}$ of hepatocyte suspension ( $c$ a . $2 \times 10^{6}$ cells $)$ was incubated with $\mathrm{HgCl}_{2}(0.5 \mu \mathrm{M})$ alone or in combination with the $\mathrm{CI}$ protein in varying concentrations $(0.05,0.1,0.5$, and 1$)$ for different sets of experiment for different time intervals.

Cell Viability Assessment Briefly at $2 \mathrm{~h}$ after treatment with varying concentrations of the $\mathrm{CI}$ protein and $\mathrm{HgCl}_{2}$ $(0.5 \mu \mathrm{M})$, the media were removed and cell viability was de- 
termined using the MTT assay as described elsewhere. ${ }^{31)}$

Measurement of Intracellular ROS Production Cells were loaded either with $\mathrm{HgCl}_{2}(0.5 \mu \mathrm{M})$ alone or with $\mathrm{HgCl}_{2}$ and the CI protein $(0.5 \mathrm{mg} / \mathrm{ml})$ for $2,4,8 \mathrm{~h}$ and at the end of the incubation period they were incubated again with $20 \mu \mathrm{M}$ DCFDA for $30 \mathrm{~min}$ at $37^{\circ} \mathrm{C}$ and intracellular ROS production was detected using the fluorescent intensity of the oxidant sensitive probe $\mathrm{H}_{2}$ DCFDA. ${ }^{32)}$

Assay of Antioxidant Power of Hepatocytes: Ferric Reducing/Antioxidant Power (FRAP) Assay Briefly, $50 \mu \mathrm{l}$ (nearly $1 \times 10^{5}$ cells) of normal as well as experimental hepatocytes were treated with $\mathrm{HgCl}_{2}(0.5 \mu \mathrm{M})$ alone or with $\mathrm{HgCl}_{2}$ and the CI protein $(0.5 \mathrm{mg} / \mathrm{ml})$ for $2,4,8 \mathrm{~h}$. The cell suspension was added to $1.5 \mathrm{ml}$ freshly prepared and pre-warmed $\left(37^{\circ} \mathrm{C}\right)$ FRAP reagent $(300 \mathrm{~mm}$ acetate buffer, $\mathrm{pH} 3.6,10 \mathrm{~mm}$ tripridyltriazine, (TPTZ) in $40 \mathrm{~mm} \mathrm{HCl}$ and $20 \mathrm{~mm}$ $\mathrm{FeCl}_{3} \cdot 6 \mathrm{H}_{2} \mathrm{O}$ in the ratio of $\left.10: 1: 1\right)$ and incubated at $37^{\circ} \mathrm{C}$ for $10 \mathrm{~min}$. The absorbance of the sample was read against the reagent blank $(1.5 \mathrm{ml}$ FRAP reagent $+50 \mu \mathrm{l}$ distilled water) at $593 \mathrm{~nm}^{33)}$

Estimation of Lipid Peroxidation Product from Liver and Kidney Homogenates Lipid peroxidation in terms of thiobarbituric acid reactive substances (TBARS) formation was measured using the method of Esterbauer and Cheeseman. ${ }^{34)}$ Experimental samples containing $1 \mathrm{mg}$ protein each were mixed with $1 \mathrm{ml}$ TCA $(20 \%), 2 \mathrm{ml}$ TBA $(0.67 \%)$ and heated for $1 \mathrm{~h}$ at $100^{\circ} \mathrm{C}$. After cooling, the precipitate was removed by centrifugation. The absorbance of each sample was measured at $535 \mathrm{~nm}$ against a blank containing all the reagents except the sample. TBARS concentration of the liver and kidney samples were calculated using the extinction coefficient of MDA which is $1.56 \times 10^{5} \mathrm{M}^{-1} \mathrm{~cm}^{-1}$ since $99 \%$ of TBARS exists as MDA.

Assay of Anti-oxidant Enzymes The CAT activity was measured in various liver and kidney homogenates following the method of Bonaventura. ${ }^{35)}$ About $5 \mu \mathrm{g}$ protein from each of the liver and kidney homogenates were mixed with $2.1 \mathrm{ml}$ of $7.5 \mathrm{mM} \mathrm{H}_{2} \mathrm{O}_{2}$ and time scan was performed for $10 \mathrm{~min}$ at $240 \mathrm{~nm}$ and the temperature, $25^{\circ} \mathrm{C}$. The disappearance of peroxide depending on the CAT activity was observed. One unit of CAT activity is defined as the amount of enzyme, which reduces $1 \mu \mathrm{mol}$ of $\mathrm{H}_{2} \mathrm{O}_{2}$ per minute.

The SOD activity was assayed following the method originally developed by Nishikimi et al. ${ }^{36)}$ and then modified by Kakkar et al. ${ }^{37)}$ About $5 \mu \mathrm{g}$ protein of liver and kidney homogenates were mixed with sodium pyrophosphate buffer, Phenazine methosulphate (PMT) and Nitro Blue tetrazolium (NBT). The reaction was started by the addition of NADH. Then the reaction mixture was incubated at $30^{\circ} \mathrm{C}$ for $90 \mathrm{~s}$ and stopped by the addition of $1 \mathrm{ml}$ of glacial acetic acid. The absorbance of the chromogen formed was measured at $560 \mathrm{~nm}$. One unit of SOD activity is defined as the enzyme concentration required to inhibit chromogen production by $50 \%$ in 1 min under the assay condition.

In all the experimental samples, the GPx activity were measured according to the method of Flohe and Ginzler ${ }^{38)}$ using $\mathrm{H}_{2} \mathrm{O}_{2}$ and NADPH as substrates. The conversion of NADPH to $\mathrm{NADP}^{+}$was observed by recording the changes in absorption intensity at $340 \mathrm{~nm}$ and one unit of enzyme activity is defined as the amount of enzyme that catalyzes the oxidation of $1 \mu \mathrm{mol}$ NADPH per minute.
Estimation of GSH and GSSG The glutathione status was assessed by the method of Hissin and Hilf. ${ }^{39)}$ This method is based on the reaction of $O$-phthaldehyde (OPT) as a fluorescent reagent with reduced glutathione $(\mathrm{GSH})$ at $\mathrm{pH}$

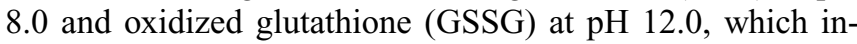
volves excitation at $350 \mathrm{~nm}$ and fluorescence at $420 \mathrm{~nm}$. For the GSSG estimation, GSSG was complexed to $N$-ethylmaleimide (NEM) to prevent interference of GSH with the measurement of GSSG. The values were expressed as $\mathrm{nmol} / \mathrm{mg}$ protein and the ratio of GSH/GSSG has been determined.

Liver and Kidney Histopathology Liver and kidney specimens from the normal, $\mathrm{HgCl}_{2}$-treated, the $\mathrm{CI}$ protein $+\mathrm{Hg}$-treated and $\mathrm{Hg}+$ the $\mathrm{CI}$ protein-treated mice were fixed in $10 \%$ buffered formalin $(10 \mathrm{ml}$ of $40 \%$ formaldehyde, $0.4 \mathrm{~g} \mathrm{NaH} \mathrm{PO}_{4} \cdot 2 \mathrm{H}_{2} \mathrm{O}, 0.65 \mathrm{~g} \mathrm{Na} \mathrm{HPO}_{4}$ and $90 \mathrm{ml}$ distilled water, $\mathrm{pH}$ 7.4) and were processed for paraffin sectioning. Sections of about $5 \mu \mathrm{m}$ thickness were stained with haematoxylin and eosin to study the structural changes of the liver and kidney.

Statistical Analysis All the values are represented as mean \pm S.D. $(n=6)$. Statistical comparison between groups were analysed by ANOVA and post hoc comparisons were done with Bonferroni corrections. $p$ values of 0.05 or less were considered significant.

\section{RESULTS}

Effect of the CI Protein on Serum GPT, ALP, Creatinine and BUN Level Parenteral administration of $\mathrm{HgCl}_{2}$ increased the level of serum GPT, ALP, urea (BUN) and creatinine levels in serum while administration of the $\mathrm{CI}$ protein before and after $\mathrm{HgCl}_{2}$ application lowered the levels of ALP, BUN and creatinine, respectively (Table 1).

Effect of the CI Protein on Serum TNF- $\alpha$ Level TNF$\alpha$ concentration in serum following $\mathrm{HgCl}_{2}$ treatment increased rapidly with time. At $24 \mathrm{~h}$ the concentration reaches to $58 \pm 2.3 \mathrm{pg} / \mathrm{ml}$ serum (Fig. 1), which further increases to a peak value of $70 \pm 3.4 \mathrm{pg} / \mathrm{ml}$ serum by $48 \mathrm{~h}$. However, by $72 \mathrm{~h}$ the concentration is slightly lowered but is much higher than the basal level. Pretreatment of mice with the CI protein ( $2 \mathrm{mg} / \mathrm{kg}$ body weight) for $3 \mathrm{~d}$ following $\mathrm{HgCl}_{2}$ administration prevented the increase in serum TNF- $\alpha$.

Effect of the CI Protein on Cell Viability Figure 2 shows that as the CI protein concentration is increased (from 0.05 to $1.0 \mathrm{mg} / \mathrm{ml}$ ), there is a corresponding dose dependent increase in viability of cells treated with $\mathrm{HgCl}_{2}$. While hepatocytes treated with $\mathrm{HgCl}_{2}$ alone had a viability of only $31 \%$, CI protein treatment gradually increased the viability and $94 \%$ hepatocytes were viable when treated with $1 \mathrm{mg} / \mathrm{ml}$ protein. However, after increasing the CI protein concentration from 0.5 to $1.0 \mathrm{mg} / \mathrm{ml}$ there was not much significant increase in viability of hepatocytes. Therefore the CI protein concentration of $0.5 \mathrm{mg} / \mathrm{ml}$ has been used for measuring ROS formation and FRAPS studies.

Effect of the CI Protein on ROS Production $\mathrm{HgCl}_{2}$ treatment increases the flourescence intensity of the dye DCFDA in treated hepatocytes by 1.8 fold after $2 \mathrm{~h}$ of treatment and it increases it further by 2.4 fold after $8 \mathrm{~h}$ of treatment, compared to control hepatocytes (Fig. 3) indicating increased ROS formation in $\mathrm{HgCl}_{2}$-treated hepatocytes. How- 
Table 1. Effect of the CI Protein Pre- and Post-treatments on GPT, ALP, BUN and Creatinine Level in Blood Serum against $\mathrm{HgCl}_{2} \mathrm{Intoxication}(5 \mathrm{mg} / \mathrm{kg}$ Body Weight)

Pre-treatment

\begin{tabular}{|c|c|c|c|c|c|c|c|c|c|}
\hline Serum parameters & $\mathrm{N}$ & $\mathrm{Hg}_{1}$ & $\mathrm{Hg}_{2}$ & $\mathrm{Hg}_{3}$ & $\mathrm{P}+\mathrm{Hg}_{1}$ & $\mathrm{P}+\mathrm{Hg}_{2}$ & $\mathrm{P}+\mathrm{Hg}_{3}$ & $\mathrm{NAC}_{3}+\mathrm{Hg}$ & $\mathrm{BSA}_{3}+\mathrm{Hg}$ \\
\hline GPT (IU/1) & $32 \pm 1.7$ & $84 \pm 4.3 *$ & $80 \pm 4.2 *$ & $77 \pm 3.9 *$ & $79 \pm 4.0$ & $63 \pm 3.3$ & $40 \pm 1.9 * *$ & $41 \pm 1 * * *$ & $82 \pm 4.3$ \\
\hline ALP (KAunits/ml serum) & $15 \pm 1.0$ & $36 \pm 1.7 *$ & $34 \pm 1.8 *$ & $30 \pm 1.7 *$ & $31 \pm 1.7$ & $23 \pm 1.3$ & $19 \pm 1.1 * *$ & $18 \pm 0.9 * * *$ & $33 \pm 1.8$ \\
\hline BUN (Urea/100 ml serum) & $17 \pm 0.8$ & $41 \pm 2.3 *$ & $38 \pm 1.9^{*}$ & $35 \pm 1.7 *$ & $37 \pm 1.9$ & $26 \pm 1.5$ & $19 \pm 0.9 * *$ & $17 \pm 0.9 * * *$ & $38 \pm 2.0$ \\
\hline Creatinine (mg/1 serum) & $3.0 \pm 0.3$ & $9.4 \pm 0.9 *$ & $9.0 \pm 0.8^{*}$ & $8.1 \pm 0.6^{*}$ & $8.0 \pm 1.0$ & $5.0 \pm 0.7$ & $4.0 \pm 0.6^{* *}$ & $5.0 \pm 0.4 * * *$ & $7.0 \pm 0.5$ \\
\hline
\end{tabular}

Post-treatment

\begin{tabular}{|c|c|c|c|c|c|c|c|c|c|}
\hline Serum parameters & $\mathrm{N}$ & $\mathrm{Hg}_{1}$ & $\mathrm{Hg}_{2}$ & $\mathrm{Hg}_{3}$ & $\mathrm{Hg}+\mathrm{P}_{1}$ & $\mathrm{Hg}+\mathrm{P}_{2}$ & $\mathrm{Hg}+\mathrm{P}_{3}$ & $\mathrm{Hg}+\mathrm{NAC}_{3}$ & $\mathrm{Hg}+\mathrm{BSA}_{3}$ \\
\hline GPT (IU/1) & $32 \pm 1.7$ & $84 \pm 4.4 *$ & $80 \pm 4.3^{*}$ & $77 \pm 3.9 *$ & $80 \pm 4.1$ & $68 \pm 3.5$ & $50 \pm 1.0 * *$ & $37 \pm 1.9 * * *$ & $87 \pm 4.4$ \\
\hline ALP (KAunits/ml serum) & $15 \pm 1.0$ & $36 \pm 1.7 *$ & $34 \pm 1.8^{*}$ & $30 \pm 1.7 *$ & $30 \pm 1.3$ & $25 \pm 1.3$ & $18 \pm 0.9 * *$ & $18 \pm 1.1 * * *$ & $32 \pm 1.7$ \\
\hline BUN (Urea/100 ml serum) & $17 \pm 0.9$ & $41 \pm 2.2 *$ & $38 \pm 1.9 *$ & $35 \pm 1.7 *$ & $38 \pm 2.0$ & $25 \pm 1.4$ & $18 \pm 1.0 * *$ & $19 \pm 1.1 * * *$ & $40 \pm 2.0$ \\
\hline Creatinine (mg/l serum) & $3.0 \pm 0.3$ & $9.4 \pm 1 *$ & $9.0 \pm 0.9 *$ & $8.1 \pm 0.6^{*}$ & $9.0 \pm 0.9$ & $7.0 \pm 0.5$ & $4.0 \pm 0.5 * *$ & $5.0 \pm 0.2 * * *$ & $8.0 \pm 1.0$ \\
\hline
\end{tabular}

$\mathrm{N}$ : level in normal-control mice, $\mathrm{Hg}_{1}, \mathrm{Hg}_{2}, \mathrm{Hg}_{3}$ : levels in $\mathrm{HgCl}_{2}$ treated mice and sacrificed after $1,2,3 \mathrm{~d}$ respectively. $\mathrm{P}+\mathrm{Hg}_{1}, \mathrm{P}+\mathrm{Hg}_{2}, \mathrm{P}+\mathrm{Hg}_{3}$ : levels in which the $\mathrm{CI}$ protein was given at a dose $2 \mathrm{mg} / \mathrm{kg}$ body weight for $3 \mathrm{~d}$ prior to $\mathrm{HgCl}_{2}$ administration and sacrificed after $1,2,3 \mathrm{~d}$ respectively. $\mathrm{NAC}$ + $\mathrm{Hg}_{\mathrm{g}}$ levels in which $\mathrm{NAC}$ was given at a dose $150 \mathrm{mg} / \mathrm{kg}$ body weight for $3 \mathrm{~d}$ prior to $\mathrm{HgCl}_{2}$ administration. $\mathrm{BSA}_{3}+\mathrm{Hg}$ : levels in which $\mathrm{BSA}$ was given at a dose $2 \mathrm{mg} / \mathrm{kg}$ body weight for $3 \mathrm{~d}$ prior to $\mathrm{HgCl}$ administration. $\mathrm{Hg}+\mathrm{P}_{1}, \mathrm{Hg}+\mathrm{P}_{2}, \mathrm{Hg}+\mathrm{P}_{3}$ : levels in which the CI protein was given at a dose of $2 \mathrm{mg} / \mathrm{kg}$ body weight for $1,2,3 \mathrm{~d}$ respectively after $\mathrm{HgCl} \mathrm{l}_{2}$ administration for a day and sacrificed a day after the last treatment. $\mathrm{Hg}+\mathrm{NAC}_{3}$ : levels in which NAC was given at a dose $150 \mathrm{mg} / \mathrm{kg}$ body weight for $3 \mathrm{~d}$ after $\mathrm{HgCl}_{2}$ administration. $\mathrm{Hg}+\mathrm{BSA}$ : levels in which $\mathrm{BSA}$ was given at a dose $150 \mathrm{mg} / \mathrm{kg}$ body weight for $3 \mathrm{~d}$ after $\mathrm{HgCl}_{2}$ administration. Data represents mean $\pm \mathrm{S}$.D., $n=6(* p * * p$ and $* * * p<0.05)$. $* p$ indicates statistically significant difference of the values of serum markers of $\mathrm{HgCl}_{2}$-treated mice with respect to normal control; $* * p$ indicates the same with respect to the values of serum markers of the $\mathrm{CI}$ protein preand post-treated mice respectively with respect to $\mathrm{HgCl}_{2}$-treated mice and $* * * p$ indicates the same for the values of serum markers of $\mathrm{NAC}$ treated mice with respect to $\mathrm{HgCl}_{2}$ treated mice.

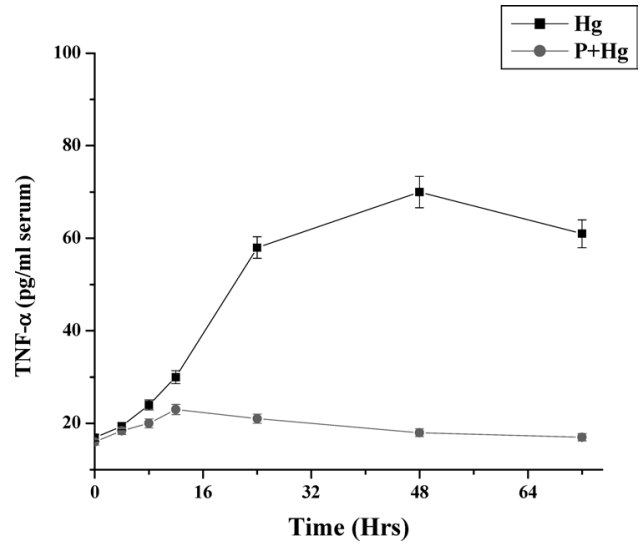

Fig. 1. Serum Levels of TNF- $\alpha$ Following Intraperitoneal Administration of $5 \mathrm{mg} / \mathrm{kg}$ Body Weight of $\mathrm{HgCl}_{2}$ (Closed Squares) or Pretreated with $2 \mathrm{mg} / \mathrm{kg}$ of the CI Protein for $3 \mathrm{~d}$ before $\mathrm{HgCl}_{2}$ Administration (Closed Circles)

Each value represents mean \pm S.E. for three different experiments performed in triplicates.

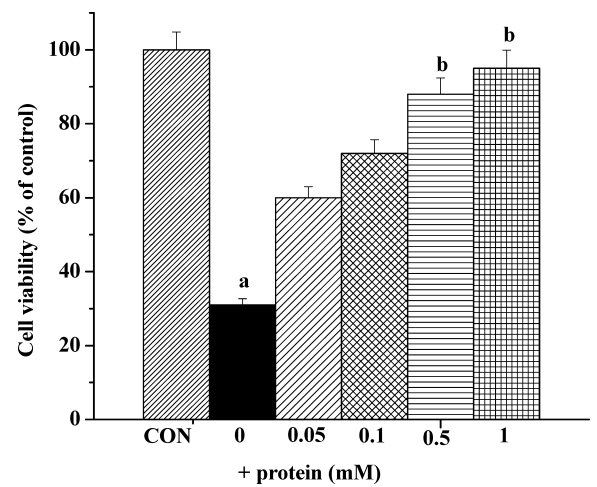

Fig. 2. Dose Dependent Effect of the CI Protein on $\mathrm{HgCl}_{2}(5 \mu \mathrm{M})$ Induced Loss of Cell Viability for $2 \mathrm{~h}$

Each value represents mean \pm S.E. for three different experiments performed in triplicates. ${ }^{a} p$ indicates statistically significant difference of cell viability of $\mathrm{HgCl}_{2}$-treated mice with respect to normal control; ${ }^{b} p$ indicates statistically significant difference of cell viability of the $\mathrm{CI}$ protein-treated mice with respect to $\mathrm{HgCl}_{2}$ treated mice.

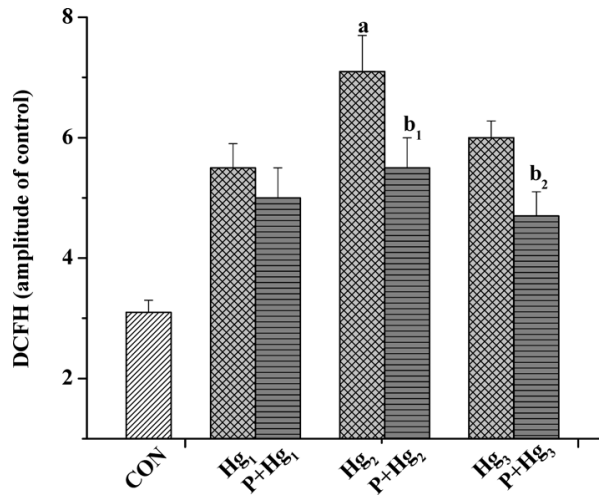

Fig. 3. Time Dependent Effect of the CI Protein on $\mathrm{HgCl}_{2}$ Induced Generation of ROS for $6 \mathrm{~h}$

CON: ROS generation in untreated cell. $\mathrm{Hg}_{1}, \mathrm{Hg}_{2}, \mathrm{Hg}_{3}$ : ROS generation in $\mathrm{HgCl}_{2}$ treated cells at a concentration of $5 \mu \mathrm{M}$ of $\mathrm{HgCl}_{2}$ for $2,4,8 \mathrm{~h}$ respectively. $\mathrm{P}+\mathrm{Hg}_{1}$, $\mathrm{P}+\mathrm{Hg}_{2}, \mathrm{P}+\mathrm{Hg}_{3}: \mathrm{ROS}$ generation in the CI protein treated $(0.5 \mathrm{mg} / \mathrm{ml}$ of protein) hepatocytes along with $5 \mu \mathrm{M}$ of $\mathrm{HgCl}_{2}$ for $2,4,8 \mathrm{~h}$ respectively. Each column represents mean \pm S.D., $n=6\left({ }^{\mathrm{a}} p,{ }^{\mathrm{b}_{1}} p,{ }^{\mathrm{b}_{2}} p<0.05\right)$. ${ }^{\mathrm{a}} p$ indicates statisticall significant difference of ROS generation in $\mathrm{HgCl}_{2}$-treated mice with respect to normal control; ${ }^{\mathrm{b}_{1}} p,{ }^{\mathrm{b}_{2}} p$ indicates the same with respect to the ROS generation of the CI protein co-treated mice along with $\mathrm{HgCl}_{2}$ for 2, 4, $8 \mathrm{~h}$ respectively with respect to their respective $\mathrm{HgCl}_{2}$-treated hepatocytes alone.

ever, hepatocytes cotreated with the CI protein and $\mathrm{HgCl}_{2}$ reduced the $\mathrm{HgCl}_{2}$ induced increase in flourescence intensity of DCFDA showing reduced generation of ROS.

Effect of the CI Protein on FRAP $\mathrm{HgCl}_{2}$ caused a significant diminution in FRAP value in a time dependent manner in isolated hepatocytes compared to hepatocytes kept in medium only (Fig. 4). A gradual reduction in FRAP value was observed with increase in time and a minimum value was obtained after $4 \mathrm{~h}$ of $\mathrm{HgCl}_{2}$ treatment. After $8 \mathrm{~h}$ of $\mathrm{HgCl}_{2}$ treatment the FRAP values slightly increase, though it was much less compared to control. However, the antioxidant power of hepatocytes measured as FRAP value increased significantly at all time points upon co-incubation with the CI protein along with $\mathrm{HgCl}_{2}$.

Effect of the CI Protein on Products of Lipid Peroxida- 
tion After administration of $\mathrm{HgCl}_{2}$, enhancement of lipid peroxidation in the liver and kidney was observed. The CI protein treatment before and after $\mathrm{HgCl}_{2}$ application protected the tissues against the increase in MDA levels and brought them back to the control values (Figs. 5A, B, respectively). The protective effects of the CI protein and NAC seemed to be similar.

Effect on Antioxidant Enzymes No significant alteration in CAT was observed in livers of $\mathrm{HgCl}_{2}$, the CI protein treated prior or post to $\mathrm{HgCl}_{2}$ treatment or in NAC treated groups of mice (Fig. 6A). However, the activity of CAT was significantly decreased in the kidney tissue of $\mathrm{HgCl}_{2}$ treated mice (Fig. 6B) and maximum reduction was observed after $2 \mathrm{~d}$ of treatment. Thereafter CAT activity slightly increased after $3 \mathrm{~d}$ of treatment indicating natural recovery. However, the CI protein pre-treatment arrested this reduction (Fig. 6B) significantly, while the same effect was not that prominent in

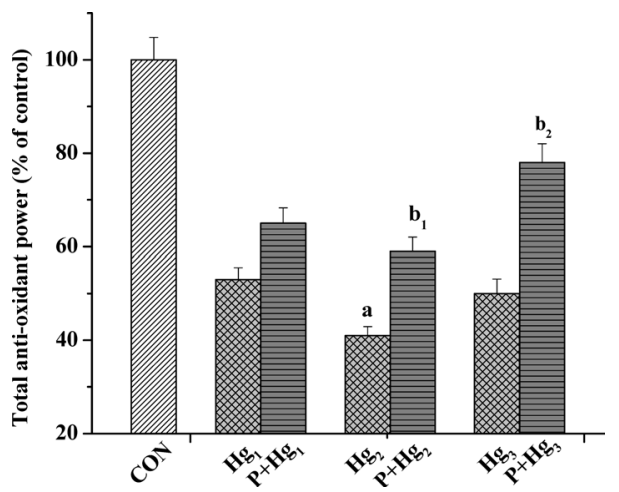

Fig. 4. Time Dependent Effect of the CI Protein on $\mathrm{HgCl}_{2}$ Induced Reduction in Total Antioxidant Power (FRAP Values) of Hepatocytes

CON: FRAP values in untreated cells. $\mathrm{Hg}_{1}, \mathrm{Hg}_{2}, \mathrm{Hg}_{3}$ : FRAP values in $\mathrm{HgCl}_{2}$ treated cells at a concentration of $5 \mu \mathrm{M}$ of $\mathrm{HgCl}_{2}$ for $2,4,8 \mathrm{~h}$ respectively. $\mathrm{P}+\mathrm{Hg}_{1}, \mathrm{P}+\mathrm{Hg}_{2}$, $\mathrm{P}+\mathrm{Hg}_{3}$ : FRAP values in the $\mathrm{CI}$ protein treated $(0.5 \mathrm{mg} / \mathrm{ml}$ of protein) hepatocytes along with $5 \mu \mathrm{M}$ of $\mathrm{HgCl}_{2}$ for $2,4,8 \mathrm{~h}$ respectively. Each column represents mean \pm S.D., $n=6$ $\left({ }^{\mathrm{a}} p,{ }^{\mathrm{b}_{1}} p,{ }^{\mathrm{b}_{2}} p<0.05\right) .{ }^{\mathrm{a}} p$ indicates statistically significant difference of FRAP values in $\mathrm{HgCl}_{2}$-treated mice with respect to normal control; ${ }^{b_{1}} p,{ }^{b_{2}} p$ indicates the same with respect to the FRAP values of the CI protein co-treated mice along with $\mathrm{HgCl}_{2}$ for 2, 4 , $8 \mathrm{~h}$, respectively with respect to their respective $\mathrm{HgCl}_{2}$-treated hepatocytes alone. protein post-treatment (Fig. 6B). On the other hand NAC treatments both before and after $\mathrm{HgCl}_{2}$ addition increased the CAT activities in kidney.

Treatment with mercury resulted in significant reduction in SOD values of liver and kidney of mercury treated mice. The CI protein pre-treatment resulted in enhanced SOD activity in the tissues examined. In liver tissues the extent of increase on protein pre-treatment was slightly more compared to normal control (Fig. 6C). In the kidney of the CI proteinpre-treated group, significant restoration was observed after the 3rd day of treatment (Fig. 6D). In case of the CI protein post-treatment the recovery was almost close to the normal in liver (Fig. 6C) while in kidney although there was an increase in SOD activity, the level remained low compared to normal (Fig. 6D). NAC treatments both before and after $\mathrm{HgCl}_{2}$ addition, however, increased the SOD activities in both liver and kidney significantly.

GPx activity in liver was significantly lowered in mercury treated mice (Fig. 6E). In kidney samples though there was a reduction in GPx activity upon $\mathrm{HgCl}_{2}$ administration it was not significant compared to normal control (Fig. 6F). Application of the $\mathrm{CI}$ protein to mice before or after $\mathrm{HgCl}_{2}$ application significantly restored the GPx activity in liver after the 3rd day of treatment, (Fig. 6E) while in kidney there was only a slight increase in activity on protein pre-treatment or post-treatment (Fig. 6F) groups. NAC treatments both before and after $\mathrm{HgCl}_{2}$ addition had significant effect in increasing the SOD activities in both liver and kidney.

Effect of the CI Protein on GSH/GSSG Ratio $\mathrm{HgCl}_{2}$ treatment decreased the GSH/GSSG ratio significantly in the mice liver and kidney homogenates. The CI protein pre or post-treatment did increase the GSH/GSSG ratio in liver (Fig. 7A) and kidney (Fig. 7B) tissues after the 3rd day of treatment, though the levels in the liver tissue were not as prominent as observed in the kidney tissue. However, after treatment with NAC the GSH/GSSG ratio in both liver and kidney were very close to the control and significantly higher than the $\mathrm{Hg}$ (II) group.
A

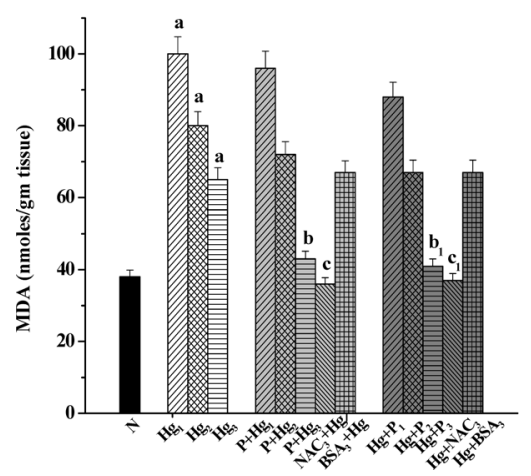

B

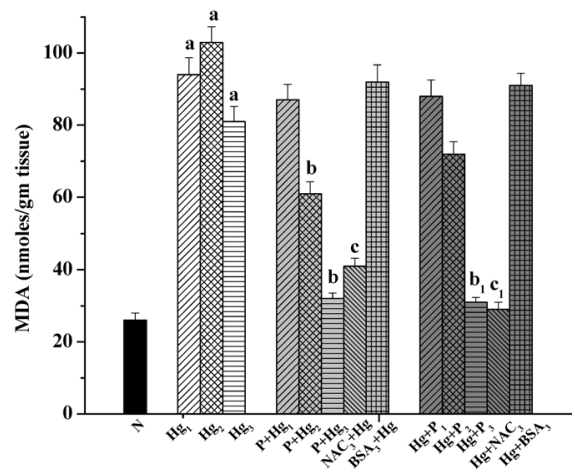

Fig. 5. Effect of the CI Protein Pre-treatment and Post-treatment against $\mathrm{HgCl}_{2}$ Intoxication on MDA Content in Liver (A) and Kidney (B)

$\mathrm{N}$ : values in normal-control mice, $\mathrm{Hg}_{1}, \mathrm{Hg}_{2}, \mathrm{Hg}_{3}$ : levels in $\mathrm{HgCl}_{2}$ treated mice and sacrificed after $1,2,3 \mathrm{~d}$ respectively. $\mathrm{P}+\mathrm{Hg}_{1}, \mathrm{P}+\mathrm{Hg}_{2}, \mathrm{P}+\mathrm{Hg}_{3}$ : levels in which the $\mathrm{CI}$ protein was given at a dose $2 \mathrm{mg} / \mathrm{kg}$ body weight for $3 \mathrm{~d}$ prior to $\mathrm{HgCl}_{2}$ administration and sacrificed after $1,2,3 \mathrm{~d}$ respectively. $\mathrm{NAC}+\mathrm{Hg}_{3}$ levels in which $\mathrm{NAC}$ was given at a dose $150 \mathrm{mg} / \mathrm{kg}$ body weight for $3 \mathrm{~d}$ prior to $\mathrm{HgCl}_{2}$ administration. $\mathrm{BSA}_{3}+\mathrm{Hg}$ : levels in which BSA was given at a dose $150 \mathrm{mg} / \mathrm{kg}$ body weight for $3 \mathrm{~d}$ prior to $\mathrm{HgCl}$ administration. $\mathrm{Hg}_{1}, \mathrm{Hg}_{2}, \mathrm{Hg}_{3}$ : levels in $\mathrm{HgCl}_{2}$ treated mice and sacrificed after 1, 2, 3 d respectively. $\mathrm{Hg}+\mathrm{P}_{1}, \mathrm{Hg}+\mathrm{P}_{2}, \mathrm{Hg}+\mathrm{P}_{3}$ : levels in which the CI protein was given at a dose of $2 \mathrm{mg} / \mathrm{kg}$ body weight for $1,2,3 \mathrm{~d}$ respectively after $\mathrm{HgCl}_{2}$ administration for a day and sacrificed a day after the last treatment. $\mathrm{NAC}+\mathrm{Hg}$ : levels in which $\mathrm{NAC}$ was given at a dose $150 \mathrm{mg} / \mathrm{kg}$ body weight for $3 \mathrm{~d}$ after $\mathrm{HgCl}_{2}$ administration. $\mathrm{BSA}_{3}+\mathrm{Hg}$ : levels in which BSA was given at a dose $150 \mathrm{mg} / \mathrm{kg}$ body weight for $3 \mathrm{~d}$ after $\mathrm{HgCl} \mathrm{l}_{2}$ administration. Data represents mean \pm S.D., $n=6\left({ }^{\mathrm{a}} p,{ }^{\mathrm{b}} p,{ }^{\mathrm{b}_{1}} p,{ }^{\mathrm{c}} p,{ }^{\mathrm{c}} p<0.05\right)$. ${ }^{\mathrm{a}} p$ indicates statistically significant difference of the indices of oxidative stress of $\mathrm{HgCl}_{2}$-treated mice with respect to normal control ${ }^{\mathrm{b}} p$ and ${ }^{\mathrm{b}_{1}} p$ indicate the same with respect to the indices of oxidative stress of CI protein pre- and post-treated mice respectively with respect to $\mathrm{HgCl}_{2}$-treated mice; ${ }^{\mathrm{c}} p$ and ${ }^{\mathrm{c}_{1}} p$ indicate the same for the indices of oxidative stress of NAC pre- and post-treated mice, respectively with respect to $\mathrm{HgCl}_{2}$-treated mice. 
A

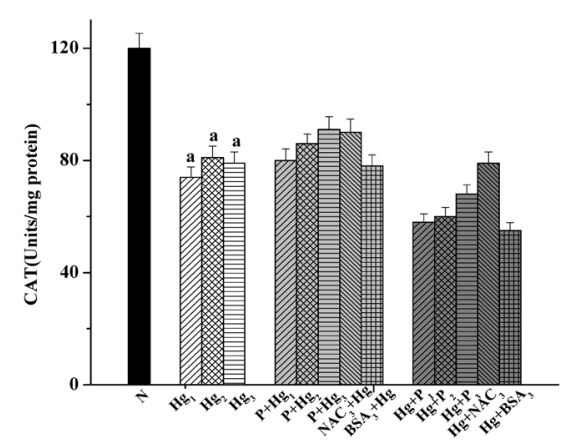

C

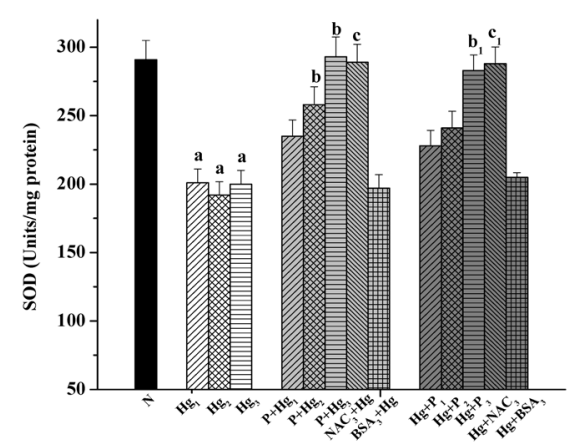

E

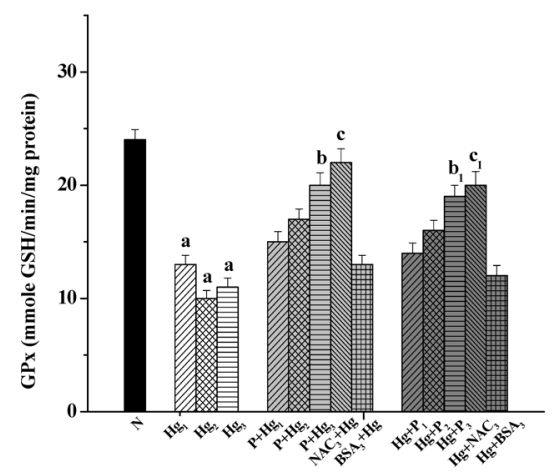

B

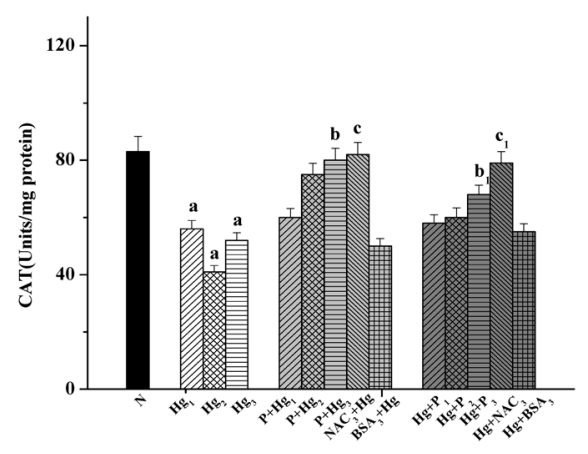

D

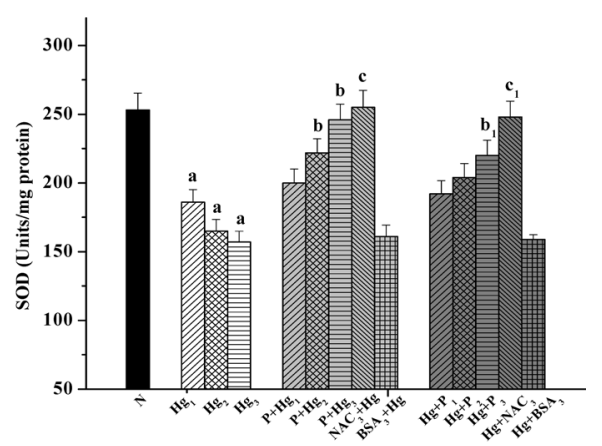

F

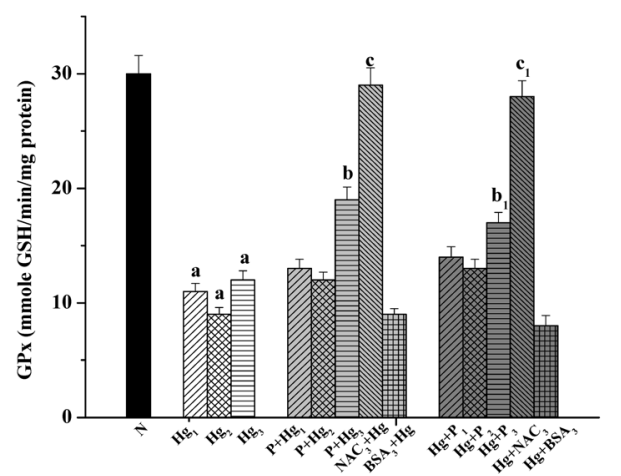

Fig. 6. Effect of the CI Protein Pre-treatment and Post-treatment against $\mathrm{HgCl}_{2}$ Intoxication on Oxidative Stress Index, CAT, Activity in Liver (A) and Kidney (B); SOD Activity in Liver (C) and Kidney (D) and GPx Activity in Liver (E) and Kidney (F)

Legend is the same as Fig. 5, except here the data are presented for CAT, SOD and GPx activities in liver and kidney.

A

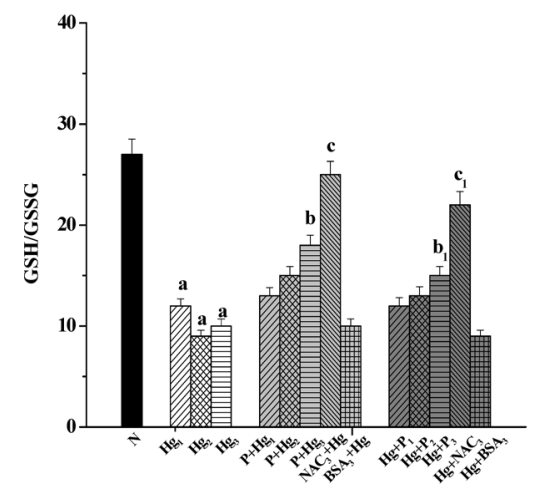

B

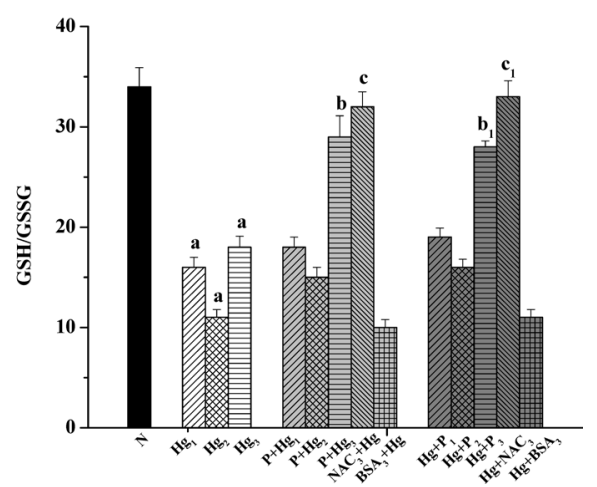

Fig. 7. Effect of the CI Protein Pre-treatment and Post-treatment against $\mathrm{HgCl}_{2}$ Intoxication on GSH/GSSG Ratio in Liver (A) and Kidney (B) Legend is the same as Fig. 5, except here the data are presented for GSH/GSSG ratio in liver (A) and kidney (B). 
A

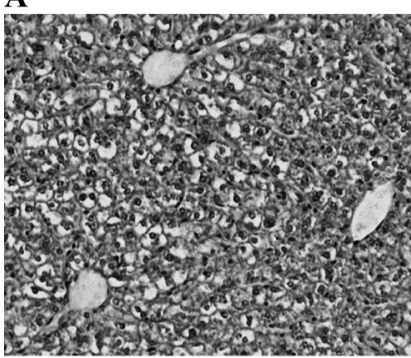

C

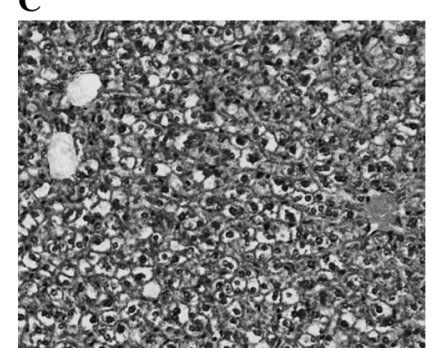

B

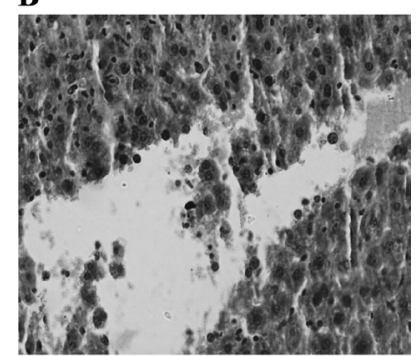

D

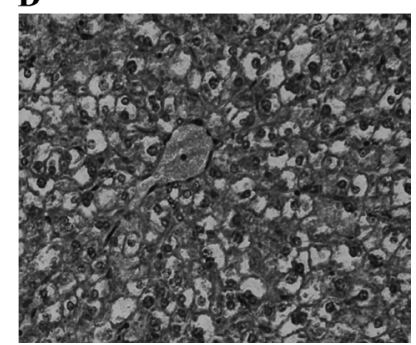

Fig. 8. Histopathology of Liver Sections Stained with HaematoxylinEosin Stain $(\times 200)$

(A) Histopathology of normal liver section. (B) Histopathology of liver treated with $\mathrm{HgCl}_{2}$ for a day and sacrificed after $48 \mathrm{~h}$. (C) Histopathology of liver treated with the $\mathrm{CI}$ protein for $3 \mathrm{~d}$ and then with $\mathrm{HgCl}_{2}$ for $1 \mathrm{~d}$ and sacrificed after $48 \mathrm{~h}$. (D) Histopathology of liver treated with $\mathrm{HgCl}_{2}$ for a day and then treated with the CI protein for $3 \mathrm{~d}$.

Effect of the CI Protein on Liver and Kidney Histopathology Histopathological analyses showed prominent changes in tissues treated with $\mathrm{HgCl}_{2}$ compared to protein pre- or post-treated tissues. In the liver tissue, $\mathrm{HgCl}_{2}$ induced necrosis along the central vein and disorganization of normal radiating pattern of cell plates around it (Fig. 8B). Besides, there was elongation and subsequent tear along the central vein in $\mathrm{HgCl}_{2}$-treated liver sections. CI protein pre-treatment showed better recovery compared to post-treatment as it almost reversed the changes observed in $\mathrm{HgCl}_{2}$ treated liver (Figs. 8C, D). In the $\mathrm{HgCl}_{2}$-treated renal sections, severe damage characterized by complete tubular necrosis with disruption of tubular basement membrane was observed (Fig. 9B). However, administration of the CI protein prior and after $\mathrm{HgCl}_{2}$ administration showed a considerable improvement in kidney (Figs. 9C, D) morphology.

\section{DISCUSSION}

In the present study, acute administration of $\mathrm{HgCl}_{2}$ caused toxic effects in the kidney and liver of the experimental animals and this damage was associated with the increase in serum GPT, ALP, BUN, creatinine and TNF- $\alpha$ as well as lipid peroxides. $\mathrm{HgCl}_{2}$ also reduced hepatocytes viability, increased ROS formation and decreased the overall antioxidant power in hepatocytes. In addition, a significant reduction was observed in CAT, SOD, GPx and GSH/GSSG ratio. $\mathrm{HgCl}_{2}$ insult resulted in severe damage in liver and kidney as revealed from histological studies. Treatment of mice with the CI protein, however, seemed to afford protection against this noxious stimulus.

Usually free radical mediated tissue injury is associated with increased circulating levels of various cytokines such as TNF- $\alpha$, Interleukin (IL)-1 $\beta$ and IL-6. Therefore, it can be proposed that antioxidants or free radical scavengers counter-

A

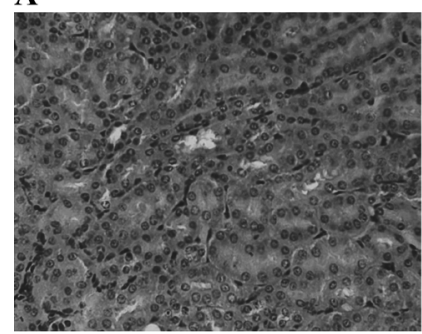

B

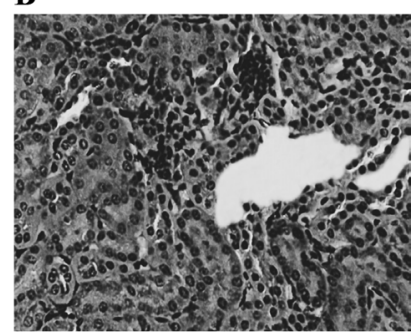

C

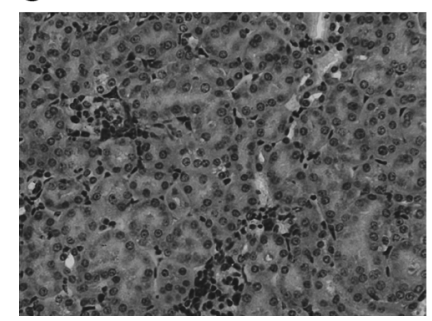

D

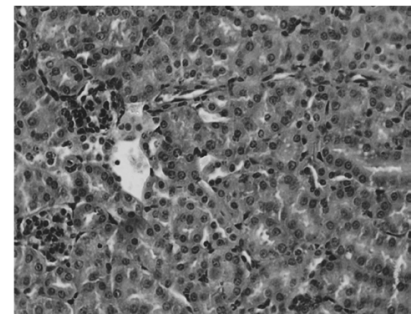

Fig. 9. Histopathology of Kidney Sections Stained with HaematoxylinEosin Stain $(\times 200)$

(A) Histopathology of normal kidney section. (B) Histopathology of kidney treated with $\mathrm{HgCl}_{2}$ for a day and sacrificed after $48 \mathrm{~h}$. (C) Histopathology of kidney treated with the CI protein for $3 \mathrm{~d}$ and then with $\mathrm{HgCl}_{2}$ for $1 \mathrm{~d}$ and sacrificed after $48 \mathrm{~h}$. (D) Histopathology of kidney treated with $\mathrm{HgCl}_{2}$ for a day and then treated with the CI protein for $3 \mathrm{~d}$.

act the oxidative stress produced by the toxins. In our study, increased TNF- $\alpha$ levels of $\mathrm{HgCl}_{2}$-treated mice appeared to decrease following the $\mathrm{CI}$ protein treatment also supports the notion that the protein ameliorates oxidative injury caused by $\mathrm{HgCl}_{2}$ probably through its antioxidant property.

Lipid peroxidation by $\mathrm{Hg}(\mathrm{II})$ has been demonstrated in the rat tissues, as well as in isolated rat hepatocytes, and it has been suggested that the cell membrane permeability may be affected by this process. ${ }^{40,41)}$ Consistent with these reports we found that mercury administration indeed increased MDA formation in both the liver and kidney tissues in mice while the CI protein treatment before and after mercury administration reversed the phenomenon.

The principal toxic effects of $\mathrm{Hg}(\mathrm{II})$ arise from alterations of mitochondrial inner membrane, which is the principal site of cellular production of reactive oxidants. Therefore, $\mathrm{HgCl}_{2}$ treatment may be accompanied by an oxidative stress-like condition. ${ }^{24,42)}$ It was found from our study that $\mathrm{HgCl}_{2}$ induced generation of ROS peaked at $4 \mathrm{~h}$, (as evidenced in DCFDA fluorescence) and the increase, was attenuated by the administration of the $\mathrm{CI}$ protein and $\mathrm{HgCl}_{2}$ for the same time. Similarly, the total antioxidant power of hepatocytes was increased when cells were incubated with the CI protein along with $\mathrm{HgCl}_{2}$ than $\mathrm{HgCl}_{2}$ alone. Thus, the results suggest that the $\mathrm{CI}$ protein possesses an antioxidative role in $\mathrm{HgCl}_{2}$ induced generation of ROS and it increases the FRAP activity as well. Moreover, $\mathrm{HgCl}_{2}$-treatment reduced the levels of several antioxidant defense molecules in liver and kidney. Though there was no significant alteration in CAT activity in livers of $\mathrm{HgCl}_{2}$ treated mice, its activity nonetheless decreased in kidneys. SOD activity, on the other hand, was reduced significantly in both liver and kidney of $\mathrm{HgCl}_{2}$-treated mice. Again GPx activity was also lowered prominently in livers and kidneys of $\mathrm{HgCl}_{2}$ administered mice. Treatment with the $\mathrm{CI}$ protein markedly ameliorated $\mathrm{HgCl}_{2}$-induced 
acute hepatic and renal oxidative stress since its administration increased the activity of CAT, SOD and GPx in both the liver and kidney.

The participation of oxidative stress in the $\mathrm{HgCl}_{2}$ associated nephrotoxicity was suggested initially by Girardi et al. ${ }^{43}$ ) and Gstraunthaler and Pfaller. ${ }^{44)}$ They showed that $\mathrm{HgCl}_{2}$ administration reduced renal GSH content and depletion of GSH resulted in increased severity of $\mathrm{HgCl}_{2}$-induced acute renal failure. Bando et $\mathrm{al}^{45)}$ have also suggested that $\mathrm{Hg}$ (II) administration selectively depletes mitochondrial GSH in liver making it more susceptible to oxidative damage, especially during increased free radical production. Our results also showed that depletion of tissue GSH/GSSG ratio, as observed in the $\mathrm{HgCl}_{2}$-induced hepatic and renal injury, is one of the major factors that permit lipid peroxidation and subsequent tissue damages. Since administration of the CI protein prevented the depletion of hepatic and renal GSH/GSSG ratio, it appears that the protective effect of the CI protein involves the maintenance of antioxidant capacity in protecting the hepatic and renal tissues against oxidative stress.

In conclusion, the outcome of our present study demonstrates that the CI protein, with its potent antioxidant properties, seems to be a highly promising agent in protecting hepatic and renal tissues against $\mathrm{HgCl}_{2}$-induced oxidative damage. It reduces $\mathrm{HgCl}_{2}$ stimulated TNF- $\alpha$ formation in serum, ROS generation in hepatocytes and increases its overall antioxidant potential. The CI protein also abrogates $\mathrm{HgCl}_{2}$-induced rise in membrane lipid peroxidation and increases the levels of antioxidant enzymes like SOD, CAT and GPx. The depleted $\mathrm{GSH} / \mathrm{GSSG}$ ratio in $\mathrm{HgCl}_{2}$ treated mice was also increased by pre or post treatment with the protein. Additionally, hepatic and renal tissue architecture was also improved in the mice pre- or post-treated with the CI protein compared to mice treated with $\mathrm{HgCl}_{2}$ alone. In this study it was also demonstrated that the $\mathrm{CI}$ protein and $\mathrm{NAC}$, in the doses used, might afford the same degree of protection against acute $\mathrm{HgCl}_{2}$ toxicity.

Acknowledgement We would like to thank Mr. Prasanta Pal for his excellent technical assistance.

\section{REFERENCES}

1) Halliwell B., Gutteridge J. M. C., Biochem. J., 219, 1-14 (1984).

2) Ichikawa I., Kiyama S., Yoshioka T., Kidney Int., 45, 1-9 (1994).

3) Ward R. J., Abiaka C., Peters T. J., J. Nephrol., 7, 89-95 (1994).

4) Stacey N. H., Kappas H., Toxicol. Appl. Pharmacol., 63, 29-35 (1982).

5) Woods J. S., Calas C. A., Aicher L. D., Robinson B. H., Mailer C., Mol. Pharmacol., 38, 253-260 (1990).

6) Huang Y. L., Chen S. L., Lin T. H., Biol. Trace Elem. Res., 52, 193 206 (1996).

7) Mahboob M., Shireen K. F., Atkinson A., Khan A. T., J. Environ. Sci. Health, 36, 687-697 (2001)

8) Sanders B. M., Goering P. L., Jenkins K., "Toxicology of Metals," ed. by Chang L. W., CRC Press, Boca Raton, Florida, 1996, pp. 165-187.
9) Addaya S., Chakravarti K., Basu A., Santra M., Haldar S., Chatterjee G. C., Acta Vitaminol. Enzymol., 6, 103-107 (1984).

10) Fukino H., Toxicol. Appl. Pharmacol., 73, 395-401 (1984).

11) Nath A., Croatt A. J., Likely S., Behrens T. W., Warden D., Kidney Int., 50, 1032-1043 (1996).

12) Paller M. S., J. Lab. Clin. Med., 105, 459-463 (1985).

13) Sarkar K., Ghosh A., Kinter A., Mazumder B., Sil P. C., Protein J., 25, $411-421$ (2006).

14) Kirtikar K. R., Basu B. D., "Indian Medicinal Plants Vol. I,” ed. by Blatter E., Caius J. F., Mhaskarr R. S., Probasi Press, Calcutta, 1935, p. 809.

15) Ghosh A., Biswas K., "Bhartiya Banausadhi," ed. by Chatterjee A., Calcutta University Press, Calcutta, 1973, pp. 332-334.

16) Manna P., Sinha M., Sil P. C., J. Biochem. Mol. Biol., 40, 382-395 (2007).

17) Sinha M., Manna P., Sil P. C., BMC. Complement. Altern. Med., 7, 11 (2007).

18) Ghosh A., Sarkar K., Sil P. C., J. Biochem. Mol. Biol., 39, 197-207 (2006).

19) Ghosh A., Sil P. C., Drug Chem. Toxicol., 29, 397-413 (2006).

20) Sarkar K., Ghosh A., Sil P. C., Hepatol. Res., 33, 39-49 (2005).

21) Kelly G. S., Altern. Med. Rec., 3, 114-127 (1998).

22) Sarkar K., Sil P. C., Toxicol. In Vitro, 20, $634-640$ (2006).

23) Bradford M. M., Anal. Biochem., 72, 248-254 (1976).

24) Lund B. O., Miller D. M., Woods J. S., Biochem. Pharmacol., 45, 2017-2024 (1993).

25) Reitman S., Frankel S. A., Am. J. Clin. Pathol., 28, 56-63 (1957).

26) Kind P. R. N., King E. J., J. Clin. Pathol., 7, 322-326 (1954).

27) Marsh W. H., Fingerhut B., Miller H., Clin. Chem., 11, 624-627 (1965).

28) Crocker C. L., Am. J. Med. Technol., 33, 361-365 (1967).

29) Bonsnes R. W., Taussky H. H., J. Biol. Chem., 158, 581-591 (1945).

30) "Current Protocols in Molecular Biology," ed. by Ausubel F. M., Brent R., Kingston R. E., Moore D. D., Siedman J. G., Smith J. A., Struhl K., Guest E. D., Albright L. M., Coen D. M., Varki A., John Wiley and Sons, Inc., New York, 2003.

31) Edmondson J. M., Armstrong S. L., Martinez A. O., Methods Cell Sci., 11, 15-17 (1988).

32) Kanno S., Tomizawa A., Hiura T., Osanai Y., Kakuta M., Kitajima Y., Koiwai K., Ohtake T., Ujibe M., Ishikawa M., Biol. Pharm. Bull., 29, 472-476 (2006).

33) Benzie I. F. F., Strain J. J., Methods Enzymol., 299, 15-27 (1999).

34) Esterbauer H., Cheeseman K. H., Methods Enzymol., 186, 407-421 (1990).

35) Bonaventura J., Schroeder W. A., Fang S., Arch. Biochem. Biophys., 150, 606-617 (1972).

36) Nishikimi M., Rao N. A., Yagi K., Biochem. Biophys. Res. Commun., 46, 849-854 (1972).

37) Kakkar P., Das B., Viswanathan P. N., Indian J. Biochem. Biophys., 21, 130-132 (1984).

38) Flohe L., Ginzler W. A., Methods Enzymol., 105, 114-121 (1984)

39) Hissin P. J., Hilf R. A., Anal. Biochem., 74, 214-226 (1976).

40) Nava M., Romero F., Quiroz Y., Parra G., Bonet L., Am. J. Physiol. Renal Physiol., 279, F910-F918 (2000).

41) Mahboob M., Shireen K. F., Atkinson A., Khan A. T., J. Environ. Sci. Health B., 36, 687-697 (2001).

42) Woods J. S., Ellis M. E., Biochem. Pharmacol., 50, 1719-1724 (1995).

43) Girardi G, Torres M. A., Elias M. M., Toxicology, 58, 187-195 (1989).

44) Gstraunthaler G., Pfaller W., Biochem. Pharmacol., 32, 2969-2972 (1983).

45) Bando I., Reus M. I. S., Andres D., Cascales M., J. Biochem. Mol. Toxicol., 19, 154-160 (2005). 